\title{
Appalachia as Trumpland: Honor, Precarity, and Affect in Literature from the Mountain South
}

\begin{abstract}
Literary and cultural texts by southern poor whites in the hills of the Ozarks and Appalachia and southern migrants in Rustbelt Ohio explode with feelings such as hatred, desperation, and anger, resulting from the continual precaritization and marginalization of the mountain communities. In (auto)biographical texts as well as in literary fiction, the "hillbilly" community is represented as self-segregated, proud, and independent, with special notions of honor and loyalty. Exploring the (dis)connections between the literary emotions of the people of the Mountain South and the code of southern honor that has produced and sustained them, this article argues that the anxious and angry emotions that Donald Trump taps into as a political strategy are not new, but rather have been building throughout the $20^{\text {th }}$ and into the $21^{\text {st }}$ centuries. The first manifestations that this precarious affective structure was forming can be seen in this regional literature, illustrating the potential in explorations of literary ugly feelings (Ngai, 2005) of marginalized southerners. Thus, the article uncovers how poor whites position their precarious existences in Trump's USA and how they employ various affective strategies to articulate their whiteness and their anxiety.
\end{abstract}

Key words: Affect, Mountain South, Precarity, Memoirs, Masculinity, Southern Honor, Trump

"Appalachia ${ }^{1}$ is a perpetual invention, a sneaky dancer that finds a way to dance somewhere out at the edge of what we think it was, what we expect it to be" (Dodd White 7), Charles Dodd White writes in his introduction to the anthology Appalachia Now (2015). Similarly, the documentary series The Appalachians begins with an introduction to the region as it is often imagined. The voice-over explains that Appalachia is "a state of mind" and has "the face of a hungry child." These representations of the region as peculiar and precarious are common, and they form the focus of much scholarly and popular work. Appalachians "are used to hard times" and "unique in their love for their fellow man" (The Appalachians ep. 1), the voice-over continues. In short: unique, tough, gritty, isolated, and unknowable, Appalachia is Other. This conception of Appalachian Otherness is not a new phenomenon and has been explored by scholars before us (see for instance Gray; Portelli; and Cunningham). Nonetheless, the articulation of this Other South to Donald Trump and reactionary politics, however imaginary the connection might be, is a new media favorite. During the 2016 campaign and after winning the election, Trump-voters were represented by many media outlets as reactionary hillbillies. Statistically, this representation does not match entirely with reality (Catte), but the notion persists, because the Mountain South continues to be the nation's scapegoat (Gibbons).

1 Although we realize the problematic nature of overgeneralization, we discuss Appalachia and the Ozarks here as if they were one community or landscape and not two separate mountain regions. We do so partly because they share inherent qualities, but mostly because in the dominant and public discourse, they are often construed as one and the same. 
Like the cultural representations of the region, the literature produced by regional mountain authors rests on received notions of Mountain Folk uniqueness, a specific sense of honor, a particular relationship to the land, and a sense of gritty, hardscrabble perseverance. Wilma Dykeman's Family of Earth (2016), Breece Pancake's The Stories of Breece D'J Pancake (1983) and J. D. Vance's Hillbilly Elegy (2016) belong in the Grit Lit genre, ${ }^{2}$ "a genre largely shaped by white male authors who are from, or at the very least write about, working-class communities, usually within the context of the U.S. South" (Vernon 78). Anger, spite and violence are central to the genre, and these affects and themes permeate the texts on all narrative levels. As Vernon points out, the grittiness of the genre adds an aura of authentic roughness to the authors' image and provides fertile ground for strategies of resistance. Similarly, in the introduction to Appalachia Now, Larry Smith argues that, "violence enters these tales at times, whether unintentional or reactionary, yet inevitable" (Smith 9). This reactionary violence, especially with authors such as Pancake and memoirists like Vance, is enmeshed in affective language that complicates the "rough" and "gritty" image; it is not simply violence for the sake of violence or anger for the sake of anger, but a complex social commentary expressed affectively, despite the fact that the South of these stories "is often wholly fabricated" (Vernon 90). In this sense, these stories are part of an archive of ugly feelings, a collection of cultural artifacts that are politically charged (Ngai).

The political qualities of these Mountain South texts are further complicated by cultural mores and a particular historical context, especially as these relate to race and gender. These complex affective worlds are both the results of and the desire for perpetuation of what is known as the Southern Culture of Honor. In the South, honor is closely tied with emotions and their expression. Honor is not an affect but rather a shared idea and concept about a person's or culture's qualities and ethos. Although it contains within it, perhaps, a desire to be virtuous or a desire for an ideal, honor in itself is not emotion(al). Nor is it a psychological drive. However, within a southern literary and cultural context, honor becomes a catalyst for various shared and communally felt emotions - affects - that form the crux of the problem of poor, white southern mountain folks' sense of precarity and anxiety. Historically, southern honor entailed complex social rules and logics strongly tied to masculinity and aristocracy. In Southern Honor (1982), Bertram Wyatt-Brown distinguishes between two traditions of honor: "primal honor," from the Indo-European system of ethics, and a concept associated with "gentility" from the Stoic-Christian system that English humanists promoted. The latter code of conduct became central in southern evaluations of behavior. Thus, Wyatt-Brown explores the culture of honor as it relates to the aristocratic ideals adopted by the plantation owners and upper classes of the South in the antebellum period. Among these honorable values were valor, a readiness to take revenge, a ferocious masculinity, and a trust in oaths, values that had strong ties to racial superiority and "sexual honor," a troubled response to women, or as Wyatt-Brown defines it, "the

2 See Zackary Vernon (2016) and Brian Carpenter (2012), who distinguish between Rough South and Grit Lit as separate genres. As Carpenter states, Rough South, a subgenre of sorts to Grit Lit, is "unquestionably violent - Grit Lit's wilder kin or Grit Lit with its back against the wall and somebody's going to get hurt" (xxviii). 
most curiously ambiguous aspect of the whole concept in the American South" (50). It may seem surprising that these ideals are found represented in the literature of the mountain region, as this region is largely absent of aristocracy and largely settled by Scots-Irish immigrants, who brought with them a stoic value system (Batteau; Nisbet and Cohen). However, this shepherding social system has been linked by some psychologists and anthropologists to the culture of honor, in which personal property and individual honor were highly valued qualities. In Culture of Honor: The Psychology of Violence in the South (1996), Nisbet and Cohen theorized that statistically higher rates of interpersonal violence in the US South could be explained by the culture of honor. Through various social experiments Nisbet and Cohen tested their hypothesis and concluded that personal affront experienced by southerners led to increased levels of stress hormones and perceptions of dishonor (Nisbet and Cohen).

The racial aspects of the culture of honor, however, may also explain why the more egalitarian mountain society shows signs of a culture of honor structure. In White Trash (2016), Nancy Isenberg links race and class and the stigmatization of both in the antebellum age to itinerant labor and landless white settlers in the mountains. This perception of poor whites as "trash" has racial overtones, as bell hooks also discusses in Where We Stand: Class Matters (2000). The historical understanding of several races of whites, where the Irish or Celts were seen as inferior to the Saxons, for instance, transferred onto twentieth-century understandings, constructs the Scots-Irish mountain folks as an inferior kind of white (see also Painter). Similarly, Wyatt-Brown identifies strong traces of ancient stigmatization of the honorless in southern prejudice against enslaved people and their descendants and against poor whites, who, despite their "blood" disregarded community dictates and judgments (46).

More importantly for our focus in the present article, honor culture is closely linked with affect and affective social structures. Whether the honor that is challenged is real or imagined matters less than the affective responses to perceived insults or changes to the social fabric. In Wyatt-Brown's account, honor is closely linked to a variety of shaky categories, adding to the sense of anxiety that people feel when mores and rules are skirted. This tenuous foundation for honor and the attendant fragility demarcate the emotional landscape of the South. ${ }^{3}$ In the literature of the Mountain South, these foundations seem even more precarious, and the combination of loss of pre-war status for white men, the harshness of the land and the resilient people who settled there, and social and economic challenges contribute to constructing an affective landscape of malaise that permeates the narratives across genres and times. In his introduction to Appalachia Now, Smith writes about the common features of the anthologized tales that "all of these stories deal with some sense of loss - economic, land, family, age, relationship. Some surrender to that loss, while others find their way through strength and character, community building, or individual rebellion" (8). This sense of contemporary malaise that Smith expresses is central to the affective qualities of the literature from the region.

In an early representation of this Appalachian malaise, Family of Earth (2016), ${ }^{4}$ Wilma Dykeman expresses this sense of unspoken or underlying loss, dread,

3 For further discussion of the Culture of Honor, see Nisbett and Cohen (1996).

4 According to the introduction to the memoir, Dykeman wrote the text while at college in the 1940s, but it was not discovered until after her death in 2006 and subsequently published in 2016. 
and desperation. Despite being written more than 70 years before the inauguration of Donald Trump, the memoir speaks to something in our times, to the affective politics of anger, hate, and desperation that now permeate the political landscape. In politicians' speeches, on Twitter, and in the media, the underlying discontent and anxiety ascribed to the poor white American underclass bubbles forth and suggests a longing for a lost and mythical past in which honor and independence were guaranteed, albeit only to the deserving.

Some of the central events in Dykeman's life, and important structuring devices in the narrative, are 1920s consumerism and the Great Depression. Described as a catastrophe for the region, the Depression also functions as a kind of moral lesson for Wilma, when her father, Willard, reprimands her for crying because they lost all their money. "'Now look here,' Daddy said, and his tone was very quiet, 'there's to be no more crying over money in this house. We'll get along"' (55). The father personifies the stoic, hardscrabble, honorable southerner who takes pride in independence and perseverance. Simultaneously, he embodies the narrative's general critique of the mountain folk themselves. Through Willard, Dykeman shows the follies of rampant consumerism and critiques the superficiality that many in the community valued in the 1920s. She writes that Willard was disappointed as "He saw some of the men in the town grow rich and attain a long car for every member in their family," a useless performance in Willard's view, and more importantly for Dykeman, an element of consumerism only made possible through the exploitation of the mountains and their resources. With austerity well suited to the mood, Dykeman states: "We still had our old Dodge" (53).

Dykeman's memoir often slips into condescension about the mountain folk, but there is also a sense that despite the self-destructive nature of the people she grew up with, their inherent goodness and precarity make them worthy of sympathy. The father's austerity invoked in these criticisms functions as a contrastive device and illustrates simultaneously Dykeman's obsession with a lost (mythical) past. Thus, Willard becomes a disappointed and angry spokesperson for a form of conservatism that views certain people as worthy poor and others as unworthy. According to Dykeman, Willard "might speak of a common Southern fault, his chin firm with earnestness, 'Now you take people around here. They leave their tools and farm things out in the weather, free to all the rain and sun and snow. Then they wonder why they don't have anything"" (20). To some extent, the memoir seems to argue, Appalachian destitution is self-inflicted. Dykeman further portrays poverty and desperation as almost inherent qualities of the region. The people are Others, and even though the Depression may have been devastating, the precarious characteristics of the region and its folks seem to predate this catastrophic economic event. The school children are described stereotypically: "Children in the mountains are often deformed physically, or mentally and nervously impaired in some degree .... Much of it is due to frequent intermarriages" (74). When a neighbor's child stays for dinner, Dykeman is appalled by the signs of poverty on her body. "Her arms were thin and pinched, there was something ill about her whole physical frame. I, too, was thin and wiry because I was always active, but hers was a different sort of leanness. It was the leanness of lack of food and too much work, not the natural leanness of youth" (75). In scenes like this, Dykeman testifies 
to "the relentless, deadening poverty and shame" (Allison 65) that often characterizes narratives of and from the region, and it adds to the notion of the region as Other, as gritty, and as hyperprecarious.

This hyperprecarity also manifests in the narrative more covertly as a mood or an "affective atmosphere" (Anderson) that comes naturally with life and growing up in the mountains. One the one hand, this precarity seems to be a result of the effects of the Depression, which, when it strikes the community, thrusts people into a sense of doom and desperation:

Despair rushed like a wave over the city. (Men jumped out of windows, and wives followed their husbands everywhere they went because of the dark threat of suicide which hung potent in the air.) The paper became one great obituary notice, and the main city graveyard had a suicide plot. With razors, from windows, by bullets, the men of fortune ended the whirling gyrations which had caught them up and carried them along to ruin. (55)

The "utter helplessness" of the situation leads Dykeman to wonder, "what utter defeat they must have felt to have figured that death could solve its riddle better than life" (55). But she also acknowledges that "the flimsiness of the scaffolding they had pinned to was made all too apparent" (55). The Depression is not the cause of the people's precarity - it only reveals it. Precarity precedes financial disaster.

Furthermore, the sense of doom and hopelessness is an underlying phenomenon that the narrative makes use of - a tone to use Sianne Ngai's term. Defined as "a literary or cultural artifact's feeling tone: its global or organizing affect, its general disposition or orientation toward its audience and the world" (Ngai 28), a text's tone influences the affective expression and reception of a text. The tone of the memoir, then, can best be defined as anxious. As we argue elsewhere (Juncker and Kongerslev), the memoir's tone manifests itself as an unstated and almost invisible sense of precarity and anxiety. As she writes, "From the darkness and warmth of my mother's womb I had been plunged into a world where eyes and ears and hands were all needed in a struggle for existence and comprehension" (12). Her word choice is characteristic of the sense of doom that permeates the memoir, as both "plunged" and "struggle" indicate a hostile environment. Neither the source nor the cause of this hostility is ever fully articulated. It is a fact of life: "Nothing came beautiful and free alone; there was some element of worry, of sickness, death, or ruined crops, in every season and every day. The babies are into adulthood [sic] with this burden of unhappiness and responsibility heavy around them" (74). The harsh environment of the mountain region creates precarious existences that result in the people's shared sense of desperation and melancholia. Dykeman may glorify her father as a paragon of virtue, but he is an honorable man despite the environment, rather than because of it. In the same vein, the land and nature seem to encompass and provoke the sense of melancholia that saturates the narrative, so that simply being in the mountains causes existential anxiety in people:

One is born with loneliness in the mountains; its cry is ever present. When the adult realization of every man's [sic] innate aloneness comes, it is not so overwhelming if you have lived in the mountains, for something in your spirit, since 
childhood, has whispered this was so. The unfelt wind howling behind the hill, the starkness of November rains, the call of nightbirds through the silence, all are testaments to the final realization of loneliness. (82)

Like other literary artifacts from Appalachia, Dykeman's memoir is preoccupied with a sense that nature and land are peculiarly precarious and Other(ing).

In this sense, she often mirrors stereotypes about hillbillies that flourish in US culture. An early cultural historian called Appalachians "some of mankind's most clannish and enigmatic folk" (Caudill, qtd by Batteau 5) and relates this community characteristic to the land that has "nurtured" them: an "entire region [that] was matted with an immense primeval forest, so dank and so dense as to amount almost to a jungle. Immense tangles of wild grapevine clung to the tops of these forest patriarchs and combined foliage of tree and vine was so dense as to almost exclude the light from the ground beneath, casting the hollows and valleys in a deep perpetual gloom" (Caudill, qtd by Batteau 5). The strangeness and singularity of the land determines the nature of the people who inhabit it, and cultural representations of the mountain folk have often relied on these characteristics to paint an often unflattering, not to mention very white, image of the region. In The Invention of Appalachia (1990), Allen Batteau describes "the miseries of Appalachia" (4) as a consequence of industrialization:

Sudden growth had its price: the mine wars of the twenties and thirties, the poverty resulting whenever the demand for coal went slack, the political corruption that seems to accompany rapid accumulation of great fortunes, the environmental destruction of strip mining, and the thousands of mining accidents left their mark in scarred hillsides, shattered limbs, uprooted communities, and a progressive decay of the bonds of kinship and trust that knit together the mountain men and women. (4)

Although writing several decades later, like Dykeman, Batteau touches on the same discourses of destructive progress leading to poverty, desperate precarity, and loss of community cohesion. The literary and cultural images of "decaying coal camps" (4) function as shorthand for all the ills of the mountain region. In numerous documentaries and fictional accounts, the precarity experienced by the people is directly related to the loss of mining jobs, a broader cultural trope Donald Trump also frequently employs.

From the melancholy anxiety and precarity of Dykeman's postwar times to the present, there has indeed been a shift in the ways in which Appalachians portray their worlds and lives; however, the sense of precarity of the community remains. ${ }^{5}$ The Stories of Breece D'J Pancake (1983) depicts the traumatized landscape and its inhabitants in the Appalachian South, and it illustrates to $21^{\text {st }}$-century readers the fact that most change in the region seems superficial. In his foreword to the volume, which came out after the author had killed himself at 26, James Alan McPherson describes Breece Pancake as a "West Virginian, that peculiar kind of mountain-bred southerner, or part-southerner, who was just as alienated as I was in the hushed gentility of Wilson

5 Appalachian authors such as Barbara Kingsolver and Valerie Nieman, whose works seem more like descendants of Dykeman's ecocritical style, often significantly differ in affective tone, style, and genre from male authors such as Taylor Brown and Chris Offutt, whose fiction fits more neatly into the violently affective Rough South genre. 
Hall" (7). Both newly arrived at the University of Virginia, one sat in a borrowed office as a creative writing instructor when the other walked in. Jimmy Carter was running for President and had introduced to genteel white southerners another South, including African Americans and Appalachians. Six feet tall, with straw-blond hair, faded blue jeans, a checkered shirt, and a US Army belt buckle sitting atop a slight beer belly, the emerging writer looked his part but did not, like other working-class students, take on the role of professional "hillbilly." McPherson recalls that, "constitutionally, Breece Pancake was a lonely and melancholy man. And his position at the university - as a Hoyns Fellow, as a teaching assistant, and as a man from a small town in the hills of West Virginia - contributed to the cynicism and bitterness that was already in him" (9). As a writer, Pancake represented the bleak hills as well as the dark emotions of his native region.

The Appalachia of Pancake's stories comes across as a landscape of death. His working-class characters inhabit Coal Country - what is left of mines, factories and farms - and their lives spin downwards. Sitting at a strip mine, the protagonist of "The Scrapper" looks at the houses of Clayton, "where the wives had planted flowers, but the plants were all dead or dying from the constant shower of coal dust" (102). Stagnant pools smell like rot, the sun "is a hardish brown," and "the sky has a film." A locust-tree post has "a few dead morning glories cling[ing] to it" (24-25). In "The Mark," Reva remembers digging for human bones from a wooden lock house now overgrown with weeds and vines (91). The protagonist of "Trilobites," Colly, sees his eyes sockets reflected in his coffee cup and hopes his mother will sell the family farm. $\mathrm{He}$ cannot enter the yard without seeing the spot where his father fell down: "He had lain spread-eagled in the thick grass after a sliver of metal from his old wound passed to his brain." Colly recalls "how beaten his face looked with prints in it from the grass" (24). Poverty, loss, and trauma saturate the landscape. Garbage piles blend with plastic flowers; houses stand "rudely shingled in imitation-brick tar paper" (73). An ugly boardinghouse looms "three stories straight up from the flat hollow-basin." As Bo of "Fox Hunters" enters it, "noise echoed through its walls, sounds of plumbing malfunctions and boarder disagreements" (66). The region is troubled.

In his introduction to Pancake's collection of stories, McPherson describes West Virginia with houses in hollows, abandoned cars, discarded stoves and refrigerators, and narrow mountain roads. "And eyes in that region," he writes, "are trained to look either up or down: from the hollow up toward the sky or from the encircling hills down into the hollows. Horizontal vision, in that area, is rare. The sky there is circumscribed by insistent hillsides thrusting upward. It is an environment crafted by nature for the dreamer and for the resigned" (11). McPherson connects landscape and emotion, which in Pancake's native region - and in his stories - tend towards extremes. With dreams lost, what remains is what Hillary Clinton in What Happened (2017) calls "an epidemic of despair" (268). Pancake's characters inhabit the darkest parts of the affective spectrum, where sadness, pain, rage, guilt, loss, loneliness, fear, and anxiety hold them hostage.

"Trilobites," the opening story, begins as Colly steps from his truck to the brick side street and looks at the worn-down Company Hill. A concrete patch looks like Florida, where his former girlfriend, Ginny, now lives. His loss and melancholia 
drench his every step and response. A brief sexual encounter when Ginny reappears illustrates the loss of connection: "The skin of her neck is almost too white in the faded evening. I know she doesn't understand." For a moment, he forgets her name and concludes: "Ginny isn't here" (35). Other characters worry about hospital bills, or about abandonment and murder. In "The Way It Has to Be," a title resonating with the resignation McPherson identifies, Alena finds herself alone in a hotel room with Harvey, who has just killed a man while his mother watched: "Alena wondered if she still sat there, her mouth open, her son dead in the yard" (129). As Harvey points his gun at her, she apologizes for being scared, while his own eyes, "wide with fear," watch her throw up yellow bile (130). Characters fall apart, or fear they will: "I see myself scattered, every cell miles from the others. I pull them back and kneel in the dark grass" (34). They try to alleviate tension with sex, with bar brawls, with cockfights and with violence. Bo in "Fox Hunters" confides in an older waitress: "Over coffee he poured out his roil of sickness, hate, and confusion" (73). But rage consumes Pancake's southerners, as the protagonist of "A Room Forever" notes, after he has tried - in vain - to connect to others with alcohol. A brief encounter with a prostitute provides only temporary relief, and his anger increases when he later finds her dead in the street, with sliced wrists: "I stop in front of the bus station, look in on the waiting people, and think about all the places they are going. But I know they can't run away from it or drink their way out of it or die and get rid of it. It's always there, you just look at somebody and they give you a look like the Wrath of God" (60). Rage and anxiety are systemic and inescapable.

Dark emotions twist minds and bodies both. Despair and malaise seep into the bodies of West Virginians, like coal dust into pores. In "Hollow" Sally cannot support herself with prostitution, because, as she is told, "Too much free stuff floatin' 'round" (46). So hopelessly she watches TV, "as the last grains of cocaine soaked into her head" (46). The protagonists become walking corpses, created by a system which does not value them as grievable lives, inhabitants of the mountains' toxic world.

This epidemic of despair has incubated in factory closings, in land erosion, and also in southern honor. The characters try to uphold their courage, their dignity, their reputation and their masculinity, but they mostly fail. The elderly man driving the snow plow in "Time and Again" takes pride in doing his job right - he smiles at "the pretties" he makes with his machine and knows about making the salt work (84). He enjoys his professional standing and honks at the other truck plowing the uphill side. He likes it that Mr. Weeks brags about him. But bones from accidents line the roads. He thinks about his time in WWII, when "it was snowing like this when they dropped us over France" (87). He tries to count the dead bodies in France, but gives up: "I never get farther than that night it snowed." He worries about his hogs: "I should have given them more slop, but when the first one dies, the others will eat him quick enough" (84). In "Fox Hunters," Bo wants to respect his dead schoolmates, and he wants respect from his employer, who has gone into the woods with him. But darkness and grief flip into something else: "Bo felt a baseness growing within himself, felt he knew the forest better than the man with the dogs, and, for a moment, wanted to run into the darkness" (78). Honor turns into violence, so as to hide the vulnerability inside.

The author of The Stories also walked the line between honor and darkness, 
craft and compulsion. Andre Dubus III writes in the new afterword to the collection that Pancake's stories express "an almost desperate response to the world and one's perceived place in it" (185). As an oath-taker of sorts, since he swears to a strict moral code for his writing, Pancake found himself committed to his honor, materializing in his "fearlessness on the page" or in his "inherent willingness to go as deeply as the story and the characters require" (185). But he also surrendered to the world he knew and to his own negative emotions. McPherson speculates about his suicide, which cut short a promising writing career: "I believe that Breece had had a few drinks and found himself locked inside the secret room he carried around with him" (17). In this space echoes the venom of mountain-bred southerners. The secret room resembles the vulnerable space inside Wyatt-Brown's southern males, where they fought inner civil wars.

In What Happened, Hillary Clinton describes her meeting in 2016 with the Coal Country folk, after her remarks about putting coal companies out of business. The comment was widely circulated - out of context - and may have caused her defeat in West Virginia, though coal mining jobs declined further in the decades after Pancake's diagnosis of despair. Clinton knows the numbers: "Between 2011 and 2016, the bottom fell out. Nationwide, coal production fell by 27 percent. Nearly sixty thousand coal miners and contractors lost their jobs, 40 percent of them in Kentucky and West Virginia alone. Big coal companies ... went bankrupt, threatening the pensions of thousands of retired miners" (269). Like Pancake, Clinton focuses on emotional landscapes. She listens to people worried about their children's futures, to men embarrassed by their disability checks and furious about political indifference in Washington (271). But the rage of residents in Mingo County, "Ground Zero for the coal crisis," startled her. Angry protesters met her with chants for Trump and "Go home Hillary"; one woman had painted her hands blood-red and yelled about Benghazi. Clinton sums it up: "I knew I wouldn't get a warm welcome in West Virginia. That was the point of my visit, after all. But this level of anger took me aback. This wasn't just about my comments in one town hall. This was something deeper" (273).

Following the November 2016 presidential election, many flabbergasted Americans turned to J. D. Vance's memoir of a culture in crisis. His autobiographical account of family and community life in Rustbelt Ohio and Eastern Kentucky spoke to those trying to locate and comprehend the angry Trump electorate. Suddenly, Vance, who served in the Marine Corps in Iraq and graduated from Yale Law School, appeared on talk shows across the country with social analyses and discreet promotion of his timely publication of Hillbilly Elegy. Vance recounts his childhood among displaced southerners in Middletown, Ohio, and among relatives in the Appalachian South, addressing the issues that the election of Donald Trump brought to the forefront of contemporary analyses and discussions: the deterioration of cities, factory shutdowns, foreclosures during the financial crisis, racial divides, the collapse of family life, with erosion of patriarchal power structures, educational disadvantages, opioid addictions, the distance to Washington political elites and a nostalgic attachment to an elusive past. Three decades after Pancake's stories, Vance covers the same ground as the young writer, and he stresses that no single issue would explain the frustrations of white Appalachians, since the economy is intertwined with psychology in their at- 
titudes and beliefs. The honor code they brought from the South no longer works in the Rustbelt, and this loss of a significant value system results in emotional toxicity.

The courage to destroy an enemy, as Wyatt-Brown describes it (34), survives with modifications. Vance's Uncle Pet reacts like a "hillbilly" when a truck driver delivering supplies to one of his businesses tells him: "Off-load this now, you son of a bitch." Uncle Pet defends his family honor by pulling the man from the truck, beating him unconscious, and running an electric saw up and down his body (14). Reputation and respect also matter in hillbilly communities, which never share local problems with outsiders. Vance mentions an ACC News report about Appalachian America, which highlighted a local "Mountain Dew Mouth" situation: dental pain and tooth loss among young children caused by too much soda and sugar. The report was watched in the region, but totally dismissed. Residents agreed, according to Vance: "This is none of your damn business" (19). Whites in the Rustbelt respect their own but may kill those who do not care for hillbilly loyalty. At twelve, enforcing Scots-Irish honor, his grandmother fired a rifle at two local men hoisting the family cow onto a truck. Vance concludes that Mamaw, as he calls her, "loathed disloyalty, and there was no greater disloyalty than class betrayal" (14).

The physical aspect of southern honor continues in hillbilly culture, where a manly appearance goes with fury and violence. The Blanton uncles in Jackson, Kentucky, fit this bill. One older man in town is accused of raping a young girl and is found floating face-down in a nearby lake with sixteen bullet wounds in his back (16). The Blanton men enforce justice and act like predators in defending their women's socalled honor. They also leave behind what Vance calls a trail of "neglected children, cheated wives, or both" (17). The economic melt-down in Vance's world threatens masculine pride, and wounded masculinity results in domestic abuse and violence. Hillbillies belong in the aggrieved group author Michael Kimmel portrays in Angry White Men. "Seeing people insult, scream, and sometimes physically fight was just a part of our life," Vance writes. "After a while, you did not even notice it" (73). Loyalty to family, class and race comes first.

This toxic emotionality extends to the community as a whole. Vance recalls in detail the rage that propels his "Mamaw" to pour gasoline over the sleeping "Papaw" and strike a match after he returns home drunk. Hillbilly women also get out of hand. In Female Masculinity, Jack Halberstam claims that female bodies can enact masculinity as perfectly as the "heroic masculinities" we recognize, fear, or trust. Female masculinity operates not as imitation, "but actually affords us a glimpse of how masculinity is constructed as masculinity." He finds that masculinities signified by women's bodies, "are framed as the rejected scraps of dominant masculinity in order that male masculinity may appear to be the real thing. But what we understand as heroic masculinity has been produced by and across both male and female bodies" (1-2). Articulating a female masculinity in Hillbilly Elegy, Mamaw picks up young Vance from school in "her uniform of baggy jeans and a men's T-shirt - with a giant menthol cigarette hanging from her lip" (137), in this context a substitute phallus. Halberstam argues provocatively that masculinity without men highlights the naturalized correlation between maleness and power. Masculinity, in short, becomes readable the moment it leaves the white, male, privileged body. Hillary may wear her jumpsuits and come 
across as a phallic woman, but she represents only Halberstam's "rejected scraps of dominant masculinity." Trump's winning formula is to present voters with a choice between an alpha male or a "nasty woman" in the White House.

Both Pancake and Vance set their texts in a neglected, othered South and both see frustrated honor codes causing anxiety, anger, and violence. Like Pancake, Vance describes a region caught in an epidemic of despair, though the young writers leave their readers with different outcomes and solutions. Vance portrays with admiration his violent Blanton uncles and their unflinching sense of hillbilly justice and loyalty and has problems with rage himself. When driving in Cincinnati with his wife, Usha, he is cut off by another car and honks, but the other driver flips him off. At the next stop light, Vance unbuckles his seat belt and feels ready to demand an apology or fight the man himself. Usha helps him control his "raw emotions" and reminds him that "not every personal slight - from a passing motorist or a neighbor critical of my dogs - is cause for a blood feud" (246). Vance asks of hillbillies that they show similar discipline and solve their own problems: "I don't know what the answer is, but I know it starts when we stop blaming Obama or Bush or faceless companies and ask ourselves what we can do to make things better" (256). Like Dykeman many decades before him, Vance relates the precarity of the mountain folk to personal faults resulting from loss of honor and responsibility, rather than systemic issues. Like Willard Dykeman, Vance subscribes to an angry ideology of stoic independence that eschews notions of structural problems.

Pancake was angry as well. McPherson remembers his self-destructive ways: "he would get into fights in lower-class bars on the outskirts of Charlottesville, then return to show off his scars. 'These are stories,' he would say" (12). Unlike Vance, he does not serve up Republican opinions, but offers instead his readers a gift. McPherson describes Pancake as an over-the-top gift-giver, with nobody around knowing what he might want in return (13-14). His only collection offers a glimpse into life among West Virginians, with a sense of the beauty of both Appalachia and its population, problems notwithstanding. In the closing story, "First Day of Winter," Hollis takes care of his parents on a decrepit farm, since there is nobody else. He longs for escape and freedom, his frustrations reflected in nature: "The wind took his breath, beat on him, and the first light flecks of ice bounced from the fenders. The land lay brittle, open, and dead" (168). But Hollis stays on and retains his honor, and a measure of peace and hope, in the last lines of Pancake's only book: "The sun was blackened with snow, and the valley closed in quietly with humming, quietly as an hour of prayer" (169). Pancake did not find peace, but he did manage to present a gift - his stories - of southern difference. John Casey concludes in the original "Afterword" that "a good part of what he earned from struggling with his troubles remains" (178).

These authors' Appalachia - insulated, enigmatic, precarious - constitutes an Other South. The region stands apart, and the literature reflects its special status and concerns. Wilma Dykeman's Family of Earth, Breece D'J. Pancake's Stories, and J. D. Vance's Hillbilly Elegy communicate and endorse the distinctive sense of honor, the intimate connection to the land, and the harsh, unflinching persistence that characterize the region overall. The texts of these Grit Lit authors brim over with dark, often taboo emotions - hate, frustration, envy, anger among them - that find an outlet in 
domestic, communal and linguistic violence. The notion of southern honor becomes a catalytic agent for the explosive emotions of mountain residents, seventy years ago and now. In the current US political terrain, the affective landscape of Appalachia has spread outside the mountain South, since it dominates as well the ugly feelings and discourses in Washington D. C. and in Trumpland generally. The $45^{\text {th }}$ president speaks in an emotional register that hillbillies, so-called, recognize, understand and validate, and literature from the Other South might help Americans despairing of Donald J. Trump and his unruly presidency comprehend the present political scene. At the very least, Appalachians have gained a voice and a history, since Dykeman, Pancake and Vanceeach in their own way - have written the region, and its multifaceted problems, values and emotions into existence in the American canon and beyond.

\section{Works Cited}

Allison, Dorothy. "Deciding to Live." Walk Till the Dogs Get Mean: Meditations on the Forbidden from Contemporary Appalachia. Eds. Adrian Blevins and Karen Salyer McElmurray. Athens: Ohio University Press, 2015. 65-70. Ebook.

Anderson, Ben. Encountering Affect: Capacities, Apparatuses, Conditions. New York and London: Routledge, 2014. Ebook.

Anderson, Carol. White Rage: The Unspoken Truth of Our Racial Divide. London: Bloomsbury, 2016. Print.

Batteau, Allen W. The Invention of Appalachia. Tucson: The University of Arizona Press, 1990. Print.

Carpenter, Brian. "Introduction: Blood and Bone." Grit Lit: A Rough South Reader. Eds. Brian Carpenter and Tom Franklin. Columbia: University of South Carolina Press, 2012: xiii-xxxii. Print.

Catte, Elizabeth. "The votes are in - an update to 'Appalachia as Trump Country.' WordPress, Nov. 23, 2016. Web. Accessed Nov. 10, 2018.

Clinton, Hillary Rodham. What Happened. New York: Simon \& Schuster, 2017. Print. Cunningham, Rodger. "Writing on the Cusp: Double Alterity and Minority Discourse in Appalachia." The Future of Southern Letters. Eds. Jefferson Humphries and John Lowe. Oxford: Oxford University Press, 1996. 41-53. Print.

Dykeman, Wilma. Family of Earth: A Southern Mountain Childhood. Columbia: University of South Carolina Press, 2016. Print.

Gibbons, Michael. "White Trash: A Class Relevant Scapegoat for the Cultural Elite." Journal of Mundane Behavior, 5.1 (2004): 1-11. Web.

Gray, Richard. Southern Aberrations: Writers of the American South and the Problem of Regionalism. Baton Rouge: Louisiana State University Press, 2000. Print.

Halberstam, Judith. Female Masculinity. Durham: Duke University Press, 1998. Print. hooks, bell. Where We Stand: Class Matters. New York and London: Routledge, 2000. Print.

Isenberg, Nancy. White Trash: The 400-Year Untold History of Class in America. New York: Penguin Books, 2016. Print.

Juncker, Clara and Marianne Kongerslev. "Anxious Hillbillies: Reactionary Artifacts and Affects in Trump's USA." Kultur \& Klasse 126 (2018): 129-44. Print. 
Kimmel, Michael. Angry White Men: American Masculinity at the End of an Era. New York: Nation Books, 2013. Print.

Ngai, Sianne. Ugly Feelings. Cambridge: Harvard University Press, 2005. Print.

Nisbett, Richard E., and Dov Cohen. Culture of Honor: The Psychology of Violence in the South. Boulder: Westview Press, 1996. Print.

Painter, Nell Irving. The History of White People. New York: W.W. Norton \& Company, 2010. Print.

Pancake, Breece D' J. The Stories of Breece D'J. Pancake. 1983. Back Bay Books, 2002. Print.

Portelli, Alessandro. "Appalachia as Science Fiction.” Appalachian Journal, 16.1 (1988): 32-43. JSTOR.

Smith, Larry R. and Charles Dodd White, eds. Appalachia Now: Short Stories of Contemporary Appalachia. Huron, OH: Bottom Dog Publishing, 2015. Print.

Vance, J. D. Hillbilly Elegy: A Memoir of a Family and Culture in Crisis. New York: HarperCollins, 2016. Print.

Vernon, Zackary. "Romanticizing the Rough South: Contemporary Cultural Nakedness and the Rise of Grit Lit." Southern Cultures 22.3 (2016): 77-94. JSTOR.

Wyatt-Brown, Bertrand. Southern Honor: Ethics and Behavior in the Old South. Oxford and New York: Oxford University Press, 1982. Print. 